UDC 502.17:622.271(571.56)

I. V. ZENKOV ${ }^{1}$, Doctor of Engineering Sciences, Professor, zenkoviv@mail.ru

A. S. MORIN ${ }^{1}$, Head of Chair, Doctor of Engineering Sciences

V. N. VOKIN ${ }^{1}$, Candidate of Engineering Sciences, Professor

E. V. KIRYUSHINA ${ }^{1}$, Candidate of Engineering Sciences, Associate Professor

${ }^{1}$ Siberian Federal University, Krasnoyarsk, Russia

\title{
JUSTIFICATION OF DISTURBED LAND RECLAMATION AFTER OPEN PIT MINING OF KIMBERLITE PIPES IN THE REPUBLIC OF SAKHA (YAKUTIA)
}

Introduction

The demand for natural diamonds has been growing worldwide since the middle of the 20th century. Russia holds a welldeserved position in the international subsoil management connected with development of kimberlite pipes. In Russia, the diamond industry mostly uses the method of open pit mining in the northern regions of Arkhangelsk and Republic of Sakha (Yakutia). Natural landscapes in these territories have heavily suffered from the large-scale environmental impact due to mining.

Geographically, the diamond-extracting regions lie nearby the Arctic Circle. Here, under conditions of prevailing negative night temperatures within 8-9 months a year, any type vegetation cover damaged by mining recovers extremely slowly. As known, open pit mining of any size exerts a substantial aggravating effect on the natural environment. For this reason, any mineral mining areas, including diamond production, draw close attention of ecologists on all continents. Various schools in Russia and abroad are engaged in studying and handling problems of mining ecology.

At the same time, the ecological assessment of mining landscape misses satellite remote sensing which enables global investigation of disturbed lands and over a long period of time (25-30 years). This gap in Russia is bridged by the single integrated R\&D school for open pit mining studies using Earth remote sensing (ERS) jointly by the Siberian Federal University, Academician Reshetnev Siberian State University of Science and Technology as well as by the Special Design and Engineering Bureau Nauka of the Institute of Computational Technologies, Siberian Branch of the Russian Academy of Sciences. The scope of the school embraces two trends: the analysis of open pit mining data of metallic (nonmetallic) and coal deposits and the long-term monitoring of initiation and evolution of vegetative ecosystems in the areas of depleted and operating open pit mines and overburden dumps. Environmental professionals in mining are always faced with the same problems and solutions presented on a selective basis in [1-14].

\section{Urgent nature of the problem under study}

In the territory of the Republic of Sakha (Yakutia), within the limits of its diamond province, mining is completed or continues at 10 kimberlite pipes (Fig. 1) [15]. At this time, five open pit diamond mines operate in the Republic. Diamond reserves under open pit bottoms at the pipes Udachnaya, Aikhal, Mir and Internatsionalnaya are extracted using the underground method. The Mir mine is flooded after water inrush in 2017 and its operation is suspended. Both open and underground mining is executed by Udachny, Aikhal, Nyurba and Mirny Mining and Processing Plants.

In the structure of Udachny Mining and Processing Plant, a single open pit mine extracts kimberlite reserves from the Zarnitsa pipe. Two large surface mines of Nyurba MPP produce diamonds from the Nyurba and Botuoba pipes. Aikhal MPP extracts kimberlite ore from the open pits at the Komsomolskaya and Yubileinaya pipes. Surface mining of kimberlite from the Mir, Sytykan, Aikhal, Udachnaya and Internatsionalnaya

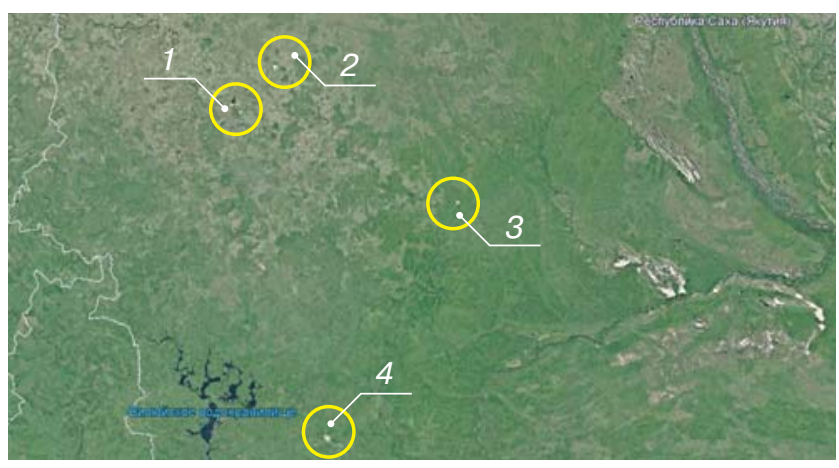

Fig. 1. Mining landscape at kimberlite pipes in the Republic of Sakha (Yakutia):

1 - Yubileinaya, Sytykan, Komsomolskaya and Aikhal pipes; 2 Udachnaya and Zarnitsa pipes; 3 - Nyurba and Botuoba pipes; 4-Mir and Internatsionalnaya pipes 
pipes has generated industrial landscapes in the form of open pits, overburden dumps and tailings ponds.

\section{Current mining operations and disturbed land ecology at open pit mines above kimberlite pipes}

Diamond deposits have a similar geological structure. Accordingly, the same mining system is used-with an increase in depth of open pits and with cutback. In the Republic of Sakha (Yakutia), surface mining operations are carried out in the geographical zone of permafrost down to a depth of $1500 \mathrm{~m}$ in places. Permafrost rocks need preliminary loosening by drilling-and-blasting before excavation. As was mentioned above, the test area accommodates 5 kimberlite pipes each developed by an open pit mine with an individual scheme of accessing working benches.

As judged by the gradually growing area of overburden dumps, the stripping ratio is $2-2.5 \mathrm{~m}^{3} / \mathrm{m}^{3}$. By estimates of this article authors, the volume of overburden is the highest in nonworking pit walls due to different angles of the kimberlite pipe crater and the pit wall.

Mining is mostly carried out at a considerable depth, with a small stripping ratio, except for the Botuoba and Nyurba pipes. This factor excludes new external dumping. The available mining and haulage equipment ensures annual capacity of the five open pit mines in terms of overburden at a level of $53 \mathrm{Mt}$. Drilling uses 15 drilling rigs SBSH-250. Excavation exploits 6 hydraulic shovels with bucket capacity of $6-15 \mathrm{~m}^{3} ; 4$ hydraulic backhoes with capacity of $2.5 \mathrm{~m}^{3} ; 12$ cable shovels (EKG-8i, EKG-10, EKG$12,5)$. Auxiliary loading makes use of 5 front-end loaders with vehicle chassis and bucket capacity of $5-10 \mathrm{~m}^{3}$. Overburden haulage operations use 108 dump trucks to $130 \mathrm{t}$ in capacity.

Such mining and haulage equipment stock is explained by heavy conditions of permafrost excavation and by geometry of kimberlite pipes, both in horizontal and vertical planes.

\section{Remote sensing of mining landscapes}

Over a short period (58 years) of mining of 10 kimberlite pipes in the Republic of Sakha (Yakutia), the area of the disturbed lands has reached 7897.1 ha. The satellite remote sensing of these lands has distinguished 7 mining-induced landscape classes purely distinct in the satellite images: sites without any vegetation cover; man-made water bodies; sites with revegetation signs; and 4 classes of area with well-developed plant formation [16]. The classes of disturbed lands and recovered vegetative ecosystems are presented in Table 1.

Table describes all main classes of mining landscape, with objects (overburden dumps and processed kimberlite storages) with this or that kind of vegetation cover. This is an exact description of the currently disturbed lands due to diamond mining in the Republic of Sakha (Yakutia). The largest area is represented by the sites without any vegetation-6087.6 ha; the smallest area is occupied by the sites with bushes and bush trees-6.3 ha.

The Earth remote sensing displays the disturbed land ecology: so far within the limits of the diamond province in the west of the Republic of Sakha (Yakutia), development of kimberlite pipes using the open pit method has considerably transformed natural land with north taiga forestation. Remote monitoring for 20 years showed the extremely slow recovery of the plant ecosystem on the land disturbed by open pit mining, as well as on the surface of objects intrinsic to the mining landscape-overburden dumps and processed kimberlite storages.
Areas of classified vegetation sites on the surface of overburden dumps and processed kimberlite storages

\begin{tabular}{|c|c|c|c|c|c|c|}
\hline \multirow{2}{*}{$\begin{array}{l}\text { Kimberlite pipe and mining } \\
\text { landscape object }\end{array}$} & \multicolumn{6}{|c|}{ Site area, ha } \\
\hline & S1 & $\mathrm{S} 2$ & S3 & S4 & S5 & S6 \\
\hline \multicolumn{7}{|l|}{ Zarnitsa: } \\
\hline Overburden dumps & 100.9 & 0 & 0 & 0 & 0 & 0 \\
\hline \multicolumn{7}{|l|}{ Udachnaya: } \\
\hline Overburden dumps & 619.4 & 0 & 0 & 0 & 9.2 & 0 \\
\hline Processed kimberlite storage & 1908.8 & 20 & 25.8 & 48.5 & 32.5 & 1.2 \\
\hline \multicolumn{7}{|c|}{ Komsomolskaya: } \\
\hline Overburden dumps & 169.8 & 0 & 0.8 & 0 & 0 & 0 \\
\hline \multicolumn{7}{|l|}{ Sytykan: } \\
\hline Overburden dumps & 192.7 & 2.3 & 0.7 & 0 & 0 & 0.9 \\
\hline \multicolumn{7}{|l|}{ Aikhal: } \\
\hline Overburden dumps & 139.3 & 0 & 2.9 & 0 & 0 & 0 \\
\hline Processed kimberlite storage & 336.5 & 0 & 2.5 & 0 & 0 & 0 \\
\hline \multicolumn{7}{|c|}{\begin{tabular}{l|l} 
Yubileinaya: &
\end{tabular}} \\
\hline Overburden dumps & 732.5 & 3.4 & 3.1 & 0 & 0 & 4.2 \\
\hline \multicolumn{7}{|l|}{ Nyurba, Botuoba: } \\
\hline Overburden dumps & 579.6 & 0 & 0 & 0 & 0 & 0 \\
\hline Processed kimberlite storage & 347.1 & 0 & 0 & 0 & 0 & 0 \\
\hline \multicolumn{7}{|c|}{ Internatsionalnaya: } \\
\hline Overburden dumps & 174.1 & 0 & 20.4 & 0 & 6.8 & 0 \\
\hline \multicolumn{7}{|l|}{ Mir: } \\
\hline Overburden dumps & 721.4 & 0 & 69.2 & 2.8 & 48.7 & 0 \\
\hline Processed kimberlite storage & 512.1 & 31.2 & 39.7 & 53.2 & 16.6 & 0 \\
\hline $\begin{array}{l}\text { Total area per classes of } \\
\text { mining landscape }\end{array}$ & 6534.2 & 56.9 & 165.1 & 104.5 & 113.8 & 6.3 \\
\hline \multicolumn{7}{|c|}{$\begin{array}{l}\text { Comments: S1 - land occupied by a mining landscape objects } \\
\text { (overburden dump of processed kimberlite ore storage); S2 - land } \\
\text { with revegetation signs; S3 - sites with grass vegetation; S4 - sites } \\
\text { with grass and shrub vegetation; S5 - sites with mature trees; S6 - } \\
\text { sites with bushes and bush trees }\end{array}$} \\
\hline
\end{tabular}

Substantiation of a disturbed land reclamation package needs analyzing ecological indices of mining-induced and natural landscapes through the comparison of their vegetation cover. The comparative analysis of the natural landscape transformation is based on the remote sensing data on the surface of 9 check-and-indicative sites (CIS) in the areas with intact soil and vegetation cover in the immediate neighborhood of mined-out or operating kimberlite pipes.

\section{Detailed remote sensing results on two CIS nearby mining operations at the Yubileinaya and Aikhal pipes}

In the immediate neighborhood of operating Yubileinaya and mined-out Aikhal open pit mines, CIS Nos. 1 and 2 have been selected on the natural landscape. The location of CIS relative to the open pits and external dumps is shown in Fig. 2. The major axis of CIS 1 is directed from the northeast to the southwest. The major axis of CIS 2 goes east westward. CIS 1 with an area of 245 ha lies at a distance of $2000 \mathrm{~m}$ from the external dump northward of the Yubileinaya open pit. CIS 2 with an area of 143.6 ha is $4650 \mathrm{~m}$ away from upper bench crest of the mined-out pit of the Aikhal kimberlite pipe.

The satellite imaging decoding aimed to determine vegetation kinds used the spectral data obtained in the infrared, red and green near-ranges of waves, which conformed with the combinations of channels RGB 432 for Landsat 5 TM and RGB 543 for Landsat 8 OLI. The choice of these channels for Landsat $5 \mathrm{TM}$ and Landsat $8 \mathrm{OLI}$ is governed by the considerable difference in the reflecting power of different vegetation types. The decoding results for CIS 1 and 2 based on the satellite imaging in July 2018 are demonstrated in Fig. $\mathbf{3}$.

Inside CIS 1 the total area of two natural water bodies is 0.4 ha; the area covered with grass and shrub vegetation is 


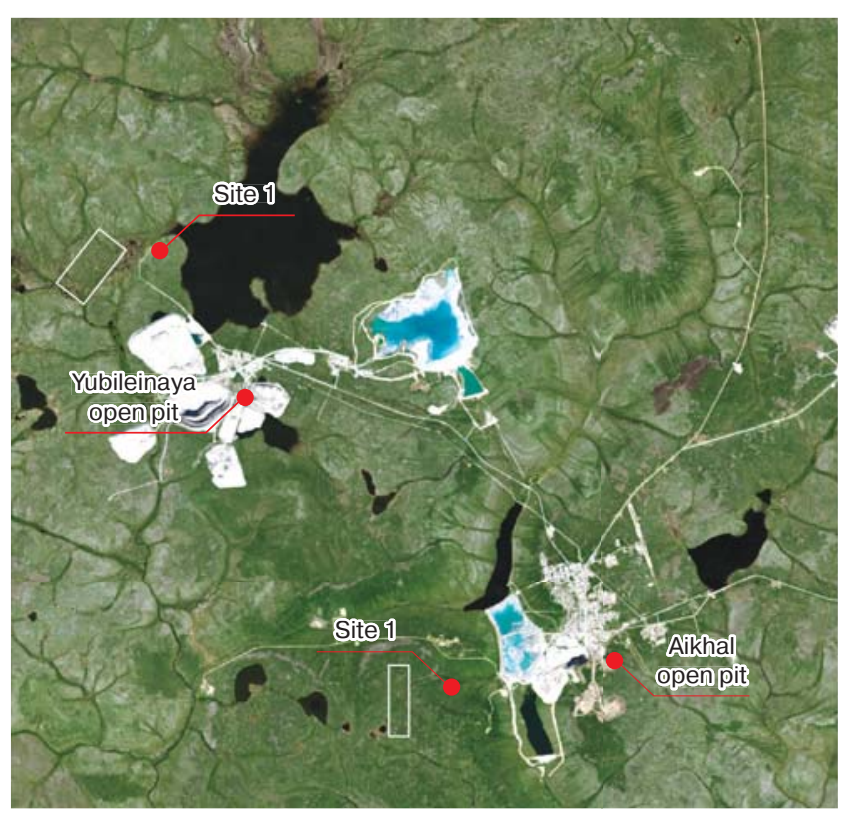

Fig. 2. Fragment of satellite image of check sites on natural landscape nearby mining areas at the Yubileinaya and Aikhal pipes (July 2018)

22.6 ha; the bog vegetation area is 222.0 ha. Within CIS 2 the vegetation cover is positively different: the thin tree vegetation covers the area of $75.7 \mathrm{ha}$; the tree vegetation area is $60.6 \mathrm{ha}$; the bog vegetation is developed on the area of 7.3 ha.

Within the boundaries of the check-and-indicative sites, the vegetation cover makes $100 \%$. The comparative analysis reveals substantial deviation of the vegetation cover ratio of the open pit mining landscape at the Aikhal and Yubileinaya pipes from the same index of CIS 1 and 2 . The vegetation cover ratio on the surface of external dumps (the pit surface is withdrawn from the calculation) is lower than on CIS 1 and 2 by the factor of 58 and 67 , respectively.

Transformation of the natural landscapes in the course of diamond mining at the Udachnaya and Zarnitsa pipes is analyzed using the remote sensing data of a single intact check site in the close proximity to the mining operations. CIS 3 is selected in the form of a regular quadrangle with an area of $505.3 \mathrm{ha}$, at a distance of $1700 \mathrm{~m}$ from the external dump in the north of the mined-out Udachnaya pit and at a distance of $14400 \mathrm{~m}$ northwestward of the west pit wall of the operating mine at the Zarnitsa pipe. Within the boundaries of CIS 3, the area of thin grass vegetation and moss is 27.4 ha, the grass vegetation covers the area of 81.1 ha; the area of thin tree vegetation is $94.8 \mathrm{ha}$, the mixed forest area is $302 \mathrm{ha}$.

Similarly to CIS 1 and 2, CIS 3 has no spots without vegetation cover, i.e. the plant formation makes $100 \%$. As it follows from the calculations, the vegetation cover ratio on the surface of external dumps and dry area of two storages of processed kimberlite ore (the pit surface is withdrawn from the calculations) at the Udachnaya pipe is 10 times lower than in CIS 3. The vegetation cover ratio on the surface of external dumps at the Zarnitsa open pit mine is zero, and it is impossible to calculate its deviation from the same index of CIS 3.

The comparative analysis of the natural landscape transformation due to mining of the Botuoba and Nyurba kimberlite pipes is performed based on the remote sensing data on two intact check sites nearby the pipes. CIS 4 is selected westward
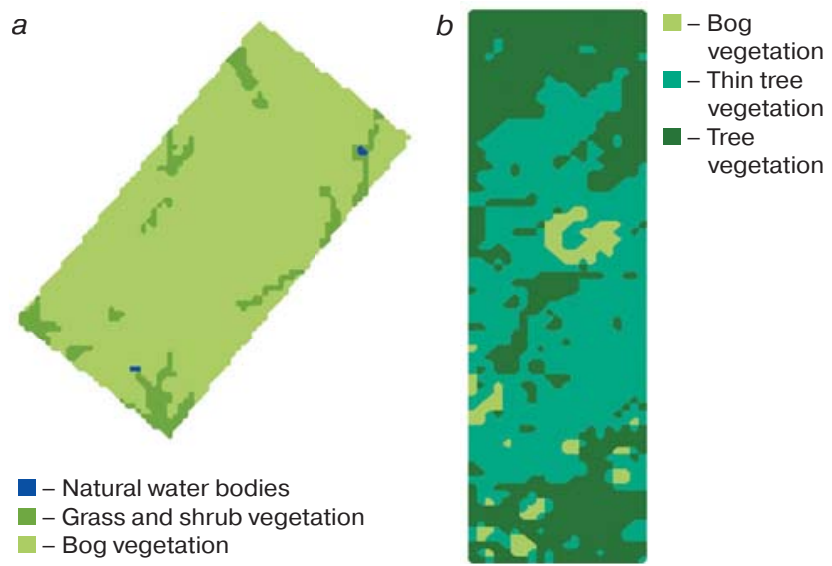

Fig. 3. Fragments of satellite image with decoding results on surfaces of check sites:

(a) CIS 1 ; (b) CIS 2

of the external dump on the west of the Nyurba open pit mine and north westward of the Botuoba open pit mine. CIS 5 is chosen in the north of the external dump of the Nyurba pit.

CIS 4 with an area of 257.1 ha lies at a distance of 2700 $\mathrm{m}$ from the external dump westward of the Nyurba pit and at a distance of 3400 north eastward of the Botuoba pit. CIS 5 with an area of 218.7 is situated at a distance of $1500 \mathrm{~m}$ from the bottom edge of the external dump northward of the Nyurba pit. Inside CIS 3 the area of a natural water body is merely 0.3 ha; the grass vegetation area is $13.9 \mathrm{ha}$; the area covered with grass-and-shrub vegetation is $9.1 \mathrm{ha}$; greenwood (birch) covers the total area of 36.6 ha; the softwood (larch) covers the area of 197.2 ha. Within CIS 5 the vegetation cover is similar to CIS 4: the grass vegetation area is 17.9 ha; grass and shrubs occupy the area of 25.9 ha; greenwood (birch) covers the total area of 17 ha; the softwood area totals 157.9 ha.

Within the boundaries of these CIS, the vegetation cover makes $100 \%$. The vegetation cover ratio on the surface of external dumps and on dry area of processed kimberlite storages (the pit surface is withdrawn from the calculations) at the Nyurba and Botuoba open pit mines is zero, which makes it impossible to calculate its deviation from the index of CIS 4 and 5 .

The comparative analysis of the natural landscape transformation in the course of diamond extraction from the Mir and Internatsionalnaya pipes is based on the remote sensing results on four intact check-and-indicative sites.

CIS 6 is chosen at a distance of 3100 morthward of the bottom edge of the external dump on the north of the Mir pit. CIS 7 with an area of $336 \mid 7$ ha lies at a distance of $5700 \mathrm{~m}$ from the west dam of the processed kimberlite ore storage. CIS 8 with an area of 377.4 ha is situated at a distance of 4500 from the bottom edge of the external dump south eastward of the Mir open pit.

CIS 9 lies on the south from the storage of processed kimberlite ore. This site has an area of $565 / 6$ ha and is spaced from the south dam of the storage by $3600 \mathrm{~m}$. Relative to the open pit mining-induced landscape of the Internatsionalnaya pipe, CIS 9 is situated at a distance of $11800 \mathrm{~m}$ eastward of the bottom edge of the external dump on the east of the pit.

All CIS have no spots without vegetation, i.e., the vegetation cover on the check sites makes $100 \%$.

The vegetation cover ratio on the surface of external dumps and dry area of two storages of processed kimberlite ore (the pit surface is withdrawn from the calculations) at the Mir open 
pit is 3.3 times smaller than the same index of $\mathrm{CIS} 7$ and 8 . The vegetation cover ratio on the surface of external dump at the Internatsionalnaya pipe is lower than the same index of CIS 6 and 7 by a factor of 5.6 .

Within the boundaries of CIS 8 , the vegetation cover is uniform, with a little of thin forest stand. The thin stand takes a small area of $3 / 3$ ha; the area of mature tress is 374.1 ha.

Inside CIS 9 the vegetation cover significantly differs from CIS 8 owing to spots of grass and shrub: the area of grass-andshrub vegetation makes 126.5 ha; the thin forest cover takes the area of 18.8 ha; the tree vegetation takes the area of 420.3 ha. In the limits of CIS 8 and 9, the vegetation cover makes $100 \%$.

The vegetation cover ratios of surface of external dumps and dry area of processed kimberlite storages (the pit surface is withdrawn from the calculations) at the Mir and Internatsionalnaya open pit mines are 3.3 and 5.6 times lower than the same indices of $\mathrm{CIS} 8$ and 9 , respectively.

\section{Disturbed land reclamation package}

A justified technology of disturbed land reclamation should always have a final objective. In the case under discussion, cost is of marginal significance as diamond mines are a highly profitable business, and the annual deduction in amount of 12-15 million Rubles cannot greatly affect the earning power. The subjects of reclamation are overburden dumps and storages of processed kimberlite ore.

The focus of the mining-induced landscape reclamation should be forestry engineering as the forest ecosystems feature the maximum percentage in the structure of vegetation cover on the damaged land under discussion. The final objective of land reclamation in our case is formation of a balanced ecosystem on the surface of each object of a mining-induced landscape. This objective is reachable upon condition of efficient generation of vegetation cover and, for the first term, the matured growing stock. The vegetation cover can be recovered in two ways (reclamation and natural self-regeneration) of formation of the critical landscape classes-grassland vegetation and softwood forest of native trees. The grassland vegetation community should include cultures that are capable of providing sufficient increment in the phytomass in the given geographical zone. The bulk phytomass, in its turn, will promote accumulation of humus and other nutrients in the productive soil layer placed on the surface of objects meant for the reclamation. As known, humic and fulvic acids are the basic nutrients for all higher vascular plants.

The most unpretentious tree capable to endure the harsh local climate for a long term is larch. Moreover, larch sheds leaves-needles every year, and they, together with other leave falls, are treated by microorganisms and become the nutrient for root systems.

For the proper formation of a vegetation ecosystem on the surface of objects meant for the reclamation, it is necessary to coat them with a man-made productive mixture capable to ensure appropriate rates of growth of planted trees. Furthermore, the knowledge is available on the quantitative and qualitative characteristics of a rich soil layer (RSL) in the natural landscape areas intended for the future mining, dumping and storage of processed kimberlite ore. For example, the soil underlying the north taiga forest, to $0.3 \mathrm{~m}$ thick, and with high content of humus in the range of $7-8 \%$. In the vertical section, RSL is underlaid with potentially rich rocks (PRR) composed of loose Quaternary rock types (clay, clay loam, sand, sand clay, etc.), up to $0.7 \mathrm{~m}$ thick.
The humus content of PRR is low, in the range of $0.6-1.0 \%$.

The present paper authors propose a new technology of a man-made productive mixture formation.

At the first stage, before removing RSL on the land assigned for the subsoil use by a dozer, bushes and trees are cut by Harvester Eco Log 580. Stubs are pulled out of ground using hydraulic manipulator LT-72. Then, the sawn down trunks, crowns and stubs are loaded in the hopper of mobile caterpillar chipper AK 635 K ECOPOWER capable of spreading chips on the ground surface. Chips are spread fanwise behind the advancing chipper. Thus, the productive mixture is added with an organic matter which, after decomposition, will be the source of nutrients for the plant community species sprouting on the surface of the reclaimed objects.

At the second stage, RSL is removed by a dozer to a depth of $0.3 \mathrm{~m}$ in the area within the limits of open pit, external dumps and processed kimberlite ore storages. In this case, due to uneven contact of RSL and PRR, they will mix. The RSL material with wood chips on its surface is piled by a dozer in temporal stockpiles to $3.0-3.5 \mathrm{~m}$ higher, with a length equal to the length of the site of the soil layer removal.

Later on, the man-made productive mixture is loaded by a hydraulic backhoe with a bucket capacity of $2 \mathrm{~m}^{3}$ to dump trucks and is hauled to permanent stockpiles with a height up to $7 \mathrm{~m}$, to be stored till application on the surface of objects meant for the reclamation.

Growth of nursery transplants of larch needs a tree farm, which is expedient to be arranged as a part of the regional forestry. This paper authors recommend to grow nursery transplants in peat pots to keep the young roots intact when bedding the plants on the reclamation objects. Upon reaching the age of 2 years, the young larch trees are planted out on the treated surface of the reclamation objects coated with a productive mixture layer $0.4 \mathrm{~m}$ thick. Bedding-out takes place in late May-early June on a pattern of $3 \times 4 \mathrm{~m}$. The plants need further nursing for 4-5 years, with removal of solute plants and filling-up of new species. In the first years, it is required to sow grass mixtures of leguminous species between the rows of the planted-out trees, for instance, Lucerne, bluegrass, etc. furthermore, the zone of the root systems of the growing tress should be applied with more compound fertilizers containing nitrogen, kalium and phosphorus. In 8-10 years, the surface of the reclaimed objects will be covered with a mature vegetation ecosystem on the basis of the north taiga softwood. Thus, the reclaimed objects will offer suitable habitality conditions for wild animals and birds.

\section{Conclusion}

After considering the remote sensing results, the conclusion has been drawn on the low performance of vegetation cover of overburden dumps and processed kimberlite storages at mining and processing plants producing diamonds from kimberlite pipes in the Republic of Sakha (Yakutia) by the open pit mining method. The highest vegetation cover ratio of 0.215 is found on the surface of processed kimberlite storages of Mirny MPP at the Mir pipe and the lowest ratio of 0.0073 belongs to the surface of overburden dumps at the Aikhal pipe. The package of reclamation measures is proposed for the industrial landscape formed in the course of kimberlite mining with regard to geographical location in the territory of Russia. The implementation of these measures will unalterably accelerate recovery of ecological balance in the areas adjacent to the objects of the mining-induced landscape. 
References

1. Safronova O. S., Lamanova T. G., Sheremet N. V. The results of the study of natural regeneration of vegetation cover on overburden dumps in the Republic of Khakassia, which emerged in the 90-years of the twentieth century. Ugol. 2018. No. 7. pp. 68-77.

2. Kharionovsky A. A., Frank E. Ya. Validation of the technology of mine technical reclamation for the purpose of reforestation in the Krutokachinskiy ballast quarry. Ugol. 2018. No. 4. pp. 75-77.

3. Pesterev A. P., Vasilieva A. I., Safroneeva S. A., Sleptsova E. V. Alteration of the northern taiga ecosystems under open pit mining. Gornyi Zhurnal. 2019. No. 2. pp. 88-91. DOI: 10.17580/ gzh.2019.02.18.

4. Krutskikh N. V. Assessment of nature transformation in the ining influence zone by earth remote sensing data. Gornyi Zhurnal. 2019. No. 3. pp. 88-93. DOI: 10.17580/gzh.2019.03.17.

5. Khairulina E. A., Kudryashova O. S., Novoselova L. V. Problems of potash tailings pile remediation. Gornyi Zhurnal. 2019. No. 5. pp. 90-94. DOI: 10.17580/gzh.2019.05.18.

6. Mesyats S. P., Novozhilova M. Yu., Rumyantseva N. S. Volkova E. Yu. Scientific substantiation of the natural ecosystems restoration disturbed during the development of georesources. Gornyi Zhurnal. 2019. No. 6. pp. 77-83. DOI: 10.17580/gzh.2019.06.11.

7. Shchadov I. M., Frank E. Ya. On the results and prospects of using ERS (Earth Remote PROBmG) resources when solving applied tasks of the coal mining industry in the global economic format. Ugol. 2018. No. 7. pp. 58-61.

8. Legostaeva Y. B., Ksenofontova M. I., Popov V. F. Geoecologic situation at site of drainage brine utilization during development of primary deposits in Yakutia. Eurasian Mining. 2019. No. 1. pp. 43-48. DOI: 10.17580/em.2019.01.11.

9. Strunk S., Houben B., Krudewig W. Controlling the Rhenish opencast mines during the transition of the energy industry. World of Mining - Surface \& Underground. 2016. Vol. 68. No. 5. pp. 289-300.

10. Ohsowski B. M., Dunfield K., Klironomos J. N., Hart M. M. Plant response to biochar, compost, and mycorrhizal fungal amendments in post-mine sandpits. Restoration Ecology. 2018, Vol. 26. pp. 63-72.

11. Fernandes K., van der Heyde M., Bunce M., Dixon K., Harris R. J. DNA metabarcoding - new approach to fauna monitoring in mine site restoration. Restoration Ecology. 2018. Vol. 26(6). pp. 1098-1107.

12. Lanterman J., Goodell K. Bumble bee colony growth and reproduction on reclaimed surface coal mines. Restoration Ecology. 2018. Vol. 26(1). pp. 183-194.

13. Abdullah M. M., Feagin R. A., Musawi L., Whisenant S., Popescu S. The use of remote sensing to develop a site history for restoration planning in an arid landscape. Restoration Ecology. 2016. Vol. 24(1). pp. 91-99.

14. Eßer G., Janz S., Walther H. Promoting biodiversity in recultivating the rhenish lignite-mining area. World of Mining - Surface and Underground. 2017. Vol. 69(6). pp. 327-334.

15. Available at: http://www.google.com/earth/ (accessed: 10.03.2020).

16. Available at: http://gis-lab.info/qa/landsat-glovis.htm (accessed: 10.03.2020). Em

\title{
UDC 502:528.8
}

\author{
N. J. ADERO ${ }^{1}$, PhD Research Student, Mine Planning \& Surveying \\ C. DREBENSTEDT ${ }^{1}$, Professor, Doctor \\ E. N. PROKOFEVA ${ }^{2}$, Associate Professor, Candidate of Engineering Sciences, eprokofyeva@hse.ru \\ A. V. VOSTRIKOV ${ }^{2}$, Associate Professor, Candidate of Engineering Sciences
}

${ }^{1}$ Freiberg University of Mining and Technology, Freiberg, Germany

${ }^{2}$ National Research University Higher School of Economics, Moscow, Russia

\section{SPATIAL DATA AND TECHNOLOGIES FOR GEOMONITORING OF LAND USE UNDER ASPECT OF MINERAL RESOURCE SECTOR DEVELOPMENT}

\section{Introduction}

As is known, a comprehensive assessment of the level of environmental violations is based on visual and quantitative data, and dynamic modelling through an indicator of the severity of environmental situations, when a satisfactory situation, the performance characteristics of the natural potential of the territory is not violated, a conflict situation is characterized by low space and time changes in landscapes, including their areas and resources reproducing properties, that is, the ability to recover in the
The main efforts of modern geoecology focus on various aspects of monitoring the state of the natural environment within the sphere of anthropogenic impacts on raw materials complexes and on determining the irreversible level of adverse impacts and consequences of natural disasters in the absence of effective tools and systems for early forecasting and detection of hazards and environmental risks (erosion, oil spills, oil and gas leaks and contamination of surface and groundwater, landslides, collapses, subsidence, mining, fire, among others). As a result, even with the highest methodological and technical level of modern research, there remains trivial conclusion on the need to protect nature. This leaves open the main question of effective methods of nature protection and the necessary changes in technologies and methods of data management.

The improvement of the methodological basis for the design of mining systems to achieve integrated development of subsoil is aimed at advancing the innovative energy and resource-saving geotechnologies, which ensure the required efficiency and safety of work, including early detection of potential hazards and risks. In this study, an integrated approach to the processing of remotely sensed data is being developed, which is envisaged to share the results of the measurements obtained in Russia and Kenya by various satellite-based technologies in both optical and radar bands.

Keywords: mining industry, digital technologies, geoecology, geomonitoring, spatial data, geotechnology, subsoil use technologies, satellite images and aerial photographs, satellite data.

DOI: 10.17580/em.2020.01.14 